\title{
PENGGUNAAN NAMA KOTA SEBAGAI NAMA DOMAIN DI INDONESIA
}

\author{
Muhamad Amirulloh \\ Fakultas Hukum Universitas Padjadjaran \\ E-mail: muhamad.amirulloh@unpad.ac.id
}

\begin{abstract}
ABSTRAK. Penggunaan nama kota sebagai nama domain oleh pihak lain tanpa ijin semakin banyak terjadi. UDRP mensyaratkan adanya persamaan atau kemiripan dengan merek agar suatu nama domain dikategorikan sebagai cybersquatting. UU Merek Amerika dan Inggris menerima perlindungan nama kota sebagai merek yang tidak terdaftar apabila nama kota tersebut memiliki "secondary meaning". UU ITE dalam Pasal 23 ayat (2) telah memberikan hak kepada pemerintah kota untuk memperoleh nama domain serta hak untuk menuntut ganti rugi berdasarkan Pasal 38. Pengaturan dalam Pasal 6 ayat (3) UU Merek belum harmonis dengan UU ITE. Permasalahan yang hendak dikaji adalah apakah penggunaan nama kota sebagai nama domain oleh pihak lain selain pemerintah kota merupakan perbuatan melawan hukum dalam bentuk cybersquatting, dan bagaimanakah sebaiknya sikap hakim di Indonesia dalam menerima dan mengadili kasus tersebut di Indonesia. Hasil penelitian menunjukkan bahwa penggunaan nama pemerintah kota sebagai nama domain tanpa ijin merupakan pelanggaran terhadap Pasal 23 ayat (2) UU ITE dan Pasal 6 ayat (3) huruf b dan c UU Merek yang ditafsirkan. Hakim sebagai penegak hukum di pengadilan harus menerima dan mengadili perkara cybersquatting terhadap nama kota di Indonesia berdasarkan ketentuan UU ITE dan melakukan penafsiran terhadap ketentuan Pasal 6 ayat (3) huruf b dan huruf c UU Merek.
\end{abstract}

Kata kunci : Harmonisasi, nama kota, nama domain, cybersquatting, penafsiran hukum

ABSTRACT. The use of city names as domain names by others without permission increasingly occur. UDRP requires the similarity or resemblance to the brand if the domain name is classified as cybersquatting. Trademark Law and the United States received the protection of the city as a common law mark, if the name of the city has "secondary meaning". UU ITE in Article 23 paragraph (2) has the right to the city government to obtain the domain name and the right to claim damages under Article 38. Indonesian Trademark Law in Article 6 paragraph (3) is not in harmony with ITE. The results showed that use of the name of the city government as a domain name without permission is a violation under Article 23 paragraph (2) of the Act ITE and Article 6 paragraph (3) letter b and c Trademark Law with interpretation. Judges must accept and adjudicate cybersquatting case against a city name in Indonesia under the provisions of the ITE Law and interpreting the provisions of Article 6 paragraph (3) letters b and c Trademark Law.

Key word: Harmonisation, city names, domain names, cybersquatting, interpretation.

\section{PENDAHULUAN}

Nama pemerintah kota mengandung makna tertentu tentang reputasi daerah tersebut, misalnya sebagai daerah penghasil suatu produk atau sebagai daerah yang kualitas produknya memiliki nilai lebih dari daerah lainnya. Nama pemerintah kota juga memiliki daya tarik yang kuat dan besar bagi pihak lain atau masyarakat terhadap informasi yang berkaitan dengan seluk beluk kota tersebut. Dalam hukum merek, pemerintah kota juga mendapatkan perlindungan dari penggunaan dan/atau pendaftaran nama kotanya sebagai merek yang dilakukan pihak lain secara tanpa ijin pemerintah kota tersebut.

Dalam internet, salah satu bentuk penggunaan nama kota adalah sebagai nama domain. Penggunaan nama domain sebagai sarana perdagangan secara elektronik (electronic commerce) menjadi salah satu strategi bisnis era millenium yang paling jitu mengingat kemampuannya dalam promosi dan distribusi produk dapat menjangkau ke seluruh pelosok dunia dalam waktu yang sangat singkat. ${ }^{1}$

\footnotetext{
${ }^{1}$ Bdgk. David Baumer, J.C. Poindexter, Cyberlaw and E-Commerce: Security, Risk Management, and Control, New York: McGraw-Hill, 2002, hlm. 297.
}

Berdasarkan data dari Pengelola Nama Domain Internet Indonesia (PANDI), jumlah nama domain yang terdaftar di Indonesia Tahun 2016 sampai bulan Nopember adalah sebanyak 231.379 nama domain. Jumlah itu meningkat kurang lebih $20 \%$ dari data bulan Januari 2016 yang hanya sebanyak 155.609 buah. Penggunaan nama domain di Indonesia terdiri dari nama domain co.id., web.id., sch.id., or.id., go.id., ac.id., mil.id., desa.id., my.id., biz.id., sebagaimana dapat digambarkan dalam Tabel $1 .^{2}$

VeriSign, Inc., vendor di bidang nama domain dan keamanan Internet, menyatakan bahwa jumlah pengguna nama domain di seluruh dunia tahun 2014 meningkat $6,8 \%{ }^{3}$ dan diprediksi akan meningkat sebanyak $10 \%$ setiap tahunnya. Perkembangan ini berpotensi diikuti dengan perkembangan sengketa kepemilikan nama domain di Indonesia, termasuk penggunaan nama kota sebagai nama domain.

Uniform Domain Name Dispute Resolution Policy (selanjutnya disebut UDRP) sebagai instrumen hukum terkait kepemilikan nama domain memiliki ${ }^{2}$ https://www.pandi.id/content/statistik, didownload tanggal 10 Januari 2017 Pukul 12.05 wib

${ }^{3} \mathrm{http}: / /$ www.infokomputer.com/2015/02/berita/berita-reguler hinggaakhir-2014-nama-domain-capai-284-juta/ 
Tabel 1. Nama Domain yang Terdaftar di Indonesia Tahun 2016

\begin{tabular}{|c|c|c|c|c|c|c|c|c|c|c|c|c|c|c|}
\hline Bln & ac.id & biz.id & co.id & desa.id & go.id & id & mil.id & my.id & net.id & or.id & sch.id & web.id & $\begin{array}{l}\text { ponpes. } \\
\text { id }\end{array}$ & Total \\
\hline Jan & 3,664 & 1,043 & 67,635 & 2,972 & 3,589 & 20,910 & 288 & 9,648 & 397 & 6,632 & 15,005 & 23,769 & 57 & 155,609 \\
\hline Feb & 3,686 & 1,097 & 68,581 & 3,027 & 3,595 & 27,347 & 290 & 9,547 & 401 & 6,793 & 15,136 & 23,766 & 58 & 163,324 \\
\hline March & 3,750 & 1,090 & 69,700 & 2,985 & 3,624 & 51,503 & 289 & 9,672 & 407 & 6,957 & 15,344 & 22,849 & 58 & 188,228 \\
\hline April & 3,807 & 1,135 & 70,687 & 2,999 & 3,648 & 52,129 & 284 & 8,224 & 406 & 7,083 & 15,531 & 22,799 & 58 & 188,790 \\
\hline May & 3,850 & 1,173 & 71,853 & 2,831 & 3,665 & 53,191 & 284 & 6,998 & 407 & 7,174 & 15,672 & 22,743 & 42 & 189,883 \\
\hline June & 3,860 & 1,173 & 71,979 & 2,782 & 3,665 & 53,159 & 284 & 6,567 & 405 & 7,195 & 16,020 & 22,817 & 43 & 189,949 \\
\hline July & 3,857 & 1,220 & 75,053 & 2,202 & 3,702 & 54,584 & 285 & 5,382 & 409 & 7,300 & 17,014 & 23,385 & 55 & 194,448 \\
\hline Aug & 3,876 & 1,345 & 78,025 & 2,011 & 3,718 & 58,221 & 288 & 4,970 & 409 & 8,027 & 17,708 & 22,807 & 161 & 201,566 \\
\hline Sep & 3,931 & 1,386 & 81,080 & 2,087 & 3,739 & 60,158 & 292 & 4,128 & 408 & 8,322 & 18,103 & 22,629 & 161 & 206,424 \\
\hline Oct & 3,977 & 1,532 & 94,682 & 2,187 & 3,753 & 63,807 & 292 & 4,180 & 410 & 8,781 & 18,838 & 23,123 & 210 & 225,772 \\
\hline Nov & 4,028 & 1,581 & 95,263 & 2,513 & 3,764 & 67,603 & 303 & 4,150 & 409 & 9,278 & 19,046 & 23,211 & 230 & 231,379 \\
\hline Dec & 4,052 & 1,621 & 96,328 & 2,612 & 3,786 & 68,733 & 305 & 4,177 & 409 & 9,525 & 19,162 & 23,249 & 235 & $1,199,045$ \\
\hline
\end{tabular}

ruang lingkup yang sangat terbatas, yaitu pada upaya pemindahan, perubahan atau penghapusan nama domain. Adanya fakta bahwa ada kerugian ekonomis akibat penggunaan merek sebagai nama domain oleh pihak lain secara tanpa hak, membuat para pemilik merek yang haknya dilanggar mencoba mencari dasar hukum untuk melakukan gugatan ganti rugi perdata. ${ }^{4}$

Kasus penggunaan nama kota sebagai nama domain sudah terjadi, misalnya kasus "Barcelona.com". Hal ini menimbulkan kerugian ekonomi bagi pemerintah kota karena hilangnya pendapatan yang seharusnya diperoleh, hilangnya potensi keuntungan, bahkan rusaknya reputasi, serta terhalanginya atau tidak dapat menggunakan nama kotanya sebagai nama domain dalam melakukan aktivitas di dunia maya (cyberspace)dengan nama domain yang telah digunakan sebelumnya. Dengan kata lain, pemerintah kota tersebut menjadi kehilangan hak eksklusif dan kesempatan dalam berbisnis di internet, padahal internet dengan e-commerce juga dapat menjadi tempat untuk melakukan kegiatan perdagangan barang dan/atau jasa.

Praktik penggunaan nama kota secara tidak sah sebagai nama domain di Indonesia antara lain Kotajogja. com, Bandung.com, dan Bali.com, perlu mendapatkan perhatian serius oleh dunia hukum, khususnya hukum merek yang merupakan bagian dari hukum Kekayaan Intelektual (selanjutnya ditulis KI). Hal ini mengingat bahwa nama kota sebagai bagian dari nama instansi pemerintah atau lembaga Negara telah dilindungi penggunaannya dalam hukum merek Pasal 23 ayat (2) Undang-Undang Nomor 11 Tahun 2008 tentang Informasi dan Transaksi Elektronik (selanjutnya ditulis UU ITE) memberikan dasar hukum bagi perlindungan

\footnotetext{
Di Indonesia, PT. Mustika Ratu tetap mencari keadilan yang diinginkan terhadap Tjandra Soegiono selaku Direktur Teknologi Informasi dan Pemasaran PT. Martina Berto, meskipun nama domain telah dipindahkan oleh NSI berdasarkan permintaan Tjandra Soegiono sebagai hasil negosiasi atau perdamaian sebagaimana dimaksud Paragraf 3 huruf a UDRP
}

terhadap hak pemerintah kota untuk menggunakan nama kotanya, dan Pasal 38 ayat (1) UU ITE memberikan dasar hukum untuk melakukan gugatan perdata terhadap cybersquatter dan typosquatter. Namun demikian, ketentuan Pasal 39 ayat (1) UU ITE menyatakan bahwa gugatan perdata dilakukan sesuai ketentuan Perturan Perundang-undangan. Hal ini menyebabkan perlunya pengkajian terhadap UU No. 15 Tahun 2001 tentang Merek (selanjutnya ditulis UU Merek) sebagai pelengkap dan pelaksana lebih lanjut dari gugatan ganti rugi dimaksud, mengingat bahwa UU Merek juga mengatur nama kota sebagai obyek perlindungan. Hal ini menyiratkan bahwa cybersquatter dan typosquatter sangat terkait erat dengan UU Merek.

Masalah yang hendak dikaji secara umum adalah persoalan tentang keberlakuan rezim hukum merek (sebagai rezim hukum dunia nyata) dalam mengatur penggunaan nama domain di internet (dunia maya, cyberspace). Secara spesifik beberapa permasalahan yang dicoba untuk ditelaah adalah sebagai berikut :

1. Bagaimanakah penggunaan nama pemerintah kota sebagai nama domain berdasarkan UU ITE dan UU Merek,?

2. Bagaimanakah sebaiknya sikap hakim Indonesia dalam menyelesaikan sengketa penggunaan nama pemerintah kota oleh pihak lain tanpa ijin sebagai nama domain?

Pasal 1 Angka 1 UU Merek, pengertian merek adalaht anda yang berupa gambar, nama, kata, hurufhuruf, angka-angka, susunan warna, atau kombinasi dari unsur-unsur tersebut yang memiliki daya pembeda dan digunakan dalam kegiatan perdagangan barang atau jasa.

Pasal 4 UU Merek menyatakan bahwa, "Merek tidak dapat didaftar atas dasar Permohonan yang diajukan oleh Pemohon yang beritikad tidak baik". 
Berdasarkan pasal ini, pemohon yang beritikad baik adalah pemohon yang mendaftarkan mereknya secara layak dan jujur tanpa ada niat untuk meniru atau menjiplak ketenaran merek pihak lain demi kepentingan usahanya yang berakibat kerugian pada pihak lain atau menyesatkan konsumen.

Pasal 6 ayat (3) huruf b menjadi pasal yang paling penting bagi perlindungan merek terkait obyek penelitian tentang perlindungan nama kota dari cybersquatting. Pasal tersebut menyatakan bahwa, "Permohonan juga harus ditolak oleh Direktorat Jenderal apabila Merek tersebut merupakan peniruan atau menyerupai nama atau singkatan nama, bendera, lambang atau simbol atau emblem, dari negara atau lembaga nasional maupun intemasional, kecuali atas persetujuan tertulis dari pihak yang berwenang".

Terhadap pelanggaran hak merek diberikan upaya hukum yang dapat ditempuh oleh pemilik merek sebagai upaya penegakan hukum merek. Pasal 76 ayat (1) menyatakan: Pemilik Merek terdaftar dapat mengajukan gugatan terhadap pihak lain yang secara tanpa hak menggunakan Merek yang mempunyai persamaan pada pokoknya atau keseluruhannya untuk barang atau jasa yang sejenis berupa:

a. gugatan ganti rugi, dan/atau

b. penghentian semua perbuatan yang berkaitan dengan penggunaan Merek tersebut.

Ketentuan ini merupakan dasar yuridis dari pemegang hak merek untuk mengajukan gugatan secara perdata atau gugatan ganti kerugian terhadap pihak yang melakukan pelanggaran hak merek. Suatu perbuatan dapat dikatakan sebagai pelanggaran hak merek apabila perbuatan tersebut melanggar hak khusus dari pemilik hak merek. Pemilik hak atas merek dan / atau penerima lisensi merek dapat mengajukan gugatan perdatanya kepada Pengadilan Niaga. ${ }^{5}$

Nama domain (domain name) dalam terminologi yuridis dapat diartikan sebagai jati diri yang digunakan sebagai identitas seseorang, perusahaan, atau badan hukum lainnya agar dapat berkomunikasi di cyberspace. Nama domain ini bisa merupakan nama perseorangan, nama perusahaan, atau bahkan nama produk tertentu. ${ }^{6}$

Menurut US Departement of Commerce, nama domain adalah nama yang paling mudah diingat untuk komputer yang terhubung dalam internet (sebagai contoh www.ecommerce.gov). Nama ini terhubung dengan nomor IP yang unik, yang digunakan untuk menunjukkan alamat komputer tersebut dalam internet. Sistem penamaan nama domain mengartikan nama internet tersebut menjadi nomor IP yang diperlukan untuk bertukar informasi dalam jaringan internet

\footnotetext{
${ }^{5}$ Pasal 76 ayat (2) dan Pasal 77 UU Merek.

${ }^{6}$ Mieke Komar Kantaatmadja et.al, Cyberlaw - Suatu Pengantar. Jakarta, ELIPS II. 2002, hlm 110.
}

tersebut. $^{7}$

Penamaan domain yang dilakukan oleh Internet Corporation for Assigned Names and Numbers (ICANN) bersifat standar dan hirarkis melalui System Distributed Database yang dikenal dengan nama Domain Name System (DNS) yang merupakan sistem penamaan domain untuk memberikan identitas atas sebuah host atau server dalam jaringan internet. Fungsi DNS dilakukan oleh sekumpulan DNS server di seluruh dunia yang terhubung secara hirarkis seperti layaknya sebuah organisasi.

Dalam sistem pendaftaran nama domain, seseorang berhak untuk mendaftarkan sebuah nama domain tanpa ada pemeriksaan substantif oleh registrar, seperti yang dikenal dalam hukum merek. Perbedaan satu karakter saja dalam suatu nama domain yang akan didaftarkan, telah memenuhi syarat bahwa suatu nama domian haruslah unik. Hal inilah yang menimbulkan pelanggaran nama domain, tidak hanya dalam bentuk penggunaan merek terdaftar sebagai nama domain oleh orang yang tidak berhak, atau penggunaan nama pemerintah kota, tetapi juga nama domain plesetan (typosite / typosquatting).

Instrumen hukum (internasional) yang dapat digunakan untuk menyelesaikan sengketa kepemilikan nama domain adalah UDRP. Uniform Domain Name Dispute Resolution Policy (UDRP) merupakan sebuah regulasi yang bersifat unik, karena bersifat global, law enforcement-nya jelas dan pasti, berlaku secara universal tanpa perlu ratifikasi, dan bersifat memaksa bagi para pihak yang menyelesaikan sengketa melalui Arbitration Provider yang ditetapkan oleh ICANN. ${ }^{8}$

Ketentuan mengenai pembatalan, pemindahan dan perubahan nama domain secara lengkap diatur dalam Paragraf 3 UDRP ,Berdasarkan ketentuan tersebut, dapat disimpulkan bahwa pihak registrar berhak untuk membatalkan, memindahkan maupun mengubah nama domain yang telah didaftarkan oleh pihak pemegang nama domain, melalui:

1.Permintaan tertulis dari pihak pemegang nama domain, dan/atau

2.Putusan atau perintah dari lembaga pengadilan maupun forum arbitrase yang berwenang, dan / atau 3. Putusan administrasi Panel berdasarkan ketentuan yang tercantum dalam UDRP.

Perbuatan mendaftarkan domain name dari namanama perusahaan maupun produk terkenal milik pihak lain tanpa izin dengan tujuan untuk menjual kembali ${ }^{7}$ Budi Agus Riswandi, Hukum dan Internet di Indonesia, Yogyakarta, UII Press, 2003, hlm. 147-148. US Department of Commerce menyatakan, "The familiar and easy to remember names for internet computer (e.g., www.ecommerce.gov). They map to unique Internet Protocol (IP) numbers (e.g., 98.37.241.30) that serve to routing address on the internet. The domain name system (DNS) translates internet names into the IP numbers needed for transmission of information across the network."

${ }^{8}$ Arbitration provider yang dilisensi oleh ICANN antara lain adalah World Intellectual Property Organisation (WIPO), National Arbitration Forum (NAF), Dispute.org/eResolution Consortium $(D e C)$, dan Asian Domain Name Dispute Resolution Centre (ADNDRC). Lebih lanjut lih. http:// http://www.icann.org/udrp/ approved-providers.htm. 
domain name tersebut, dinamakan cybersquatting. Orang yang melakukan tindakan cybersquatting disebut cybersquaters. ${ }^{9}$

Pihak yang mengajukan gugatan kepemilikan nama domain dapat siapa saja, baik perorangan maupun badan hukum yang merasa hak mereka dilanggar atas pendaftaran nama domain tersebut. ${ }^{10}$ Berdasarkan UDRP pihak penggugat harus dapat membuktikan ketiga unsur yang terdapat dalam Paragraph 4(a) agar perbuatan tergugat dapat dikategorikan sebagai tindakan cybersquatting.

Cyberpiracy tidak hanya akan menurunkan atau menghilangkan kepercayaan konsumen, tetapi juga akan menyebabkan menurunnya penggunaan internet oleh konsumen serta menghancurkan nama baik/reputasi merek-merek dan produk-produk pengusaha Amerika. ${ }^{11}$

Ketentuan Pasal 10 ayat (1) UU Nomor 48 Tahun 2009 tentang Kekuasaan Kehakiman, Lembaran Negara Tahun 2009 Nomor 157menjelaskan bahwa Pengadilan tidak boleh menolak untuk memeriksa, mengadili, dan memutus suatu perkara yang diajukan dengan dalih bahwa hukum tidak ada atau kurang jelas, melainkan wajib untuk memeriksa dan mengadilinya. Ketentuan pasal ini mengisyaratkan kepada hakim bahwa apabila terjadi suatu peraturan perundang-undangan yang belum jelas atau belum mengaturnya, hakim harus bertindak berdasar inisiatifnya sendiri untuk menyelesaikan perkara tersebut. Dalam hal ini hakim harus berperan untuk menentukan apa yang merupakan hukum, sekalipun peraturan perundang-undangan tidak dapat membantunya. Tindakan inilah yang dinamakan penemuan hukum. ${ }^{12}$

Dalam rangka menemukan hukum ini, isi ketentuan Pasal 10 ayat (1) ini hendaknya dihubungkan dengan ketentuan Pasal 5 ayat (1) yang menyatakan bahwa hakim wajib menggali, mengikuti dan memahami nilai-nilai hukum dan rasa keadilan yang hidup dalam masyarakat. Ketentuan ini dapat diartikan bahwa karena hakim merupakan perumus dan penggali dari nilai-nilai hukum yang hidup dalam masyarakat, ia seharusnya dapat mengenal, merasakan, dan mampu menyelami perasaan hukum dan rasa keadilan yang hidup dalam masyarakat. Dengan demikian, hakim dapat memberikan

\footnotetext{
H. OK. Saidin, Aspek Hukum Hak Kekayaan IntelektualIntellectual Property Rights, Jakarta, PT. Raja Grafindo Persada. 2003, hlm 529

${ }^{10}$ WIPO dalam Guide to UDRP-nya (http://arbiterwipo.int/domains/ guide/index.html) menyatakan: "Any person or company in the world can file a domain name complaint concerning a com, .net, .org, .biz, info and name domain name using the UDRP Administrative Procedure. In case of a dispute involving a domain name registered in a country code top-level domain (ccTLD), the UDRP Procedure can also be used, provided that the concerned ccTLD registration authority adopted the UDRP Policy on a voluntary basis," Lihat juga ICANN - UDRP Rules dalam http:// www.icann.org/udrp/udrp-rules-24oct99.htm: yang menyatakan "Complainant means the party initiating a complaint concerning a domain-name registration." Di download tanggal 31 Desember 2007 Pukul 23.30 wib.$$
{ }^{11} \text { Ibid }
$$

${ }^{12}$ Yudha Bhakti Ardhiwisastra, Penafsiran dan Konsytruksi Hukum, Bandung, Alumni. 2000, hlm.6-7.
}

putusan yang sesuai dengan hukum dan rasa keadilan masyarakat. $^{13}$

Jadi, tugas penting dari hakim ialah menyesuaikan undang-undang dengan hal-hal nyata di masyarakat. Apabila undang-undang tidak dapat dijalankan menurut arti katanya, hakim harus menafsirkannya. Dengan lain perkataan, apabila undang-undang tidak jelas, hakim wajib menafsirkannya sehingga ia dapat membuat suatu keputusan yang adil dan sesuai dengan maksud hukum yaitu mencapai kepastian hukum. Karena itu, orang dapat mengatakan bahwa menafsirkan undang-undang adalah kewajiban hukum dari hakim. ${ }^{14}$

Sekalipun penafsiran merupakan kewajiban hukum dari hakim, ada beberapa pembatasan mengenai kemerdekaan hakim untuk menafsirkan undang-undang itu. Logeman mengatakan bahwa hakim harus tunduk pada kehendak pembuat undang-undang. Dalam hal kehendak itu tidak dapat dibaca begitu saja dari kata-kata peraturan perundang-undangan, hakim harus mencarinya dalam sejarah kata-kata tersebut, dalam sistem undangundang atau dalam arti kata-kata seperti itu yang dipakai dalam pergaulan sehari-hari. Karena itu, menurut Polak cara penafsiran ditentukan oleh (a) materi peraturan perundang-undangan yang bersangkutan, (b) tempat perkara diajukan, dan (c) menurut zamannya. ${ }^{15}$

Agar dapat mencapai kehendak dari pembuat undang-undang serta dapat menjalankan undang-undang sesuai dengan kenyataan sosial, hakim menggunakan beberapa cara penafsiran, antara lain yaitu: ${ }^{16}$

1. Menafsirkan undang-undang menurut arti perkataan (istilah) atau biasa disebut penafsiran gramatikal.

Antara bahasa dengan hukum terdapat hubungan yang erat sekali. Bahasa merupakan alat satusatunya yang dipakai pembuat undang-undang untuk menyatakan kehendaknya. Karena itu, pembuat undang-undang yang ingin menyatakan kehendaknya secara jelas harus memilih kata-kata yang tepat. Kata-kata itu harus singkat, jelas dan tidak bisa ditafsirkan secara berlainan. Adakalanya pembuat undang-undang tidak mampu memakai kata-kata yang tepat. Dalam hal ini hakim wajib mencari arti kata yang dimaksud yang lazim dipakai dalam percakapan sehari-hari, dan hakim dapat menggunakan kamus bahasa atau meminta penjelasan dari ahli bahasa.

2. Menafsirkan undang-undang menurut cara tertentu sehingga undang-undang itu dapat dijalankan sesuai dengan keadaan sekarang yang ada di dalam masyarakat, atau biasa disebut dengan penafsiran sosiologis atau teleologis.

Setiap penafsiran undang-undang yang dimulai dengan penafsiran gramatikal harus diakhiri dengan penafsiran sosiologis. Apabila tidak demikian, keputusan

\footnotetext{
${ }^{13} \mathrm{Ibid}, \mathrm{hlm} .7$.

${ }^{14} \mathrm{Ibid}, \mathrm{hlm} .8$.

${ }^{15} \mathrm{Ibid}, \mathrm{hlm} .9$.

${ }^{16}$ Ibid, hlm. 9-11.
} 
yang dibuat tidak sesuai dengan keadaan yang benar-benar hidup dalam masyarakat. Karena itu, setiap peraturan hukum mempunyai suatu tujuan sosial, yaitu membawa kepastian hukum dalam pergaulan antara anggota masyarakat. Hakim wajib mencari tujuan sosial baru dari peraturan yang bersangkutan. Apabila hakim mencarinya, masuklah ia ke dalam lapangan pelajaran sosiologi. Melalui penafsiran sosiologi hakim dapat menyelesaikan adanya perbedaan atau kesenjangan antara sifat positif dari hukum (rechtspositiviteit) dengan kenyataan hukum (rechtswerkerlijkheid), sehingga penafsiran sosiologis atau teleologis menjadi sangat penting.

Pasal 1 angka 20 UU ITE juga diberikan definisi mengenai nama domain, yaitu: "Nama domain adalah alamat internet dari seseorang, perkumpulan, organisasi, atau badan usaha, yang dapat dilakukan untuk berkomunikasi melalui internet, yang berupa kode atau susunan karakter yang bersifat unik, menunjukkan lokasi tertentu dalam internet."

Ketentuan yang mengatur tentang nama domain terdapat dalam Bab VI tentang Nama Domain, Hak Kekayaan Intelektual, dan Perlindungan Hak Pribadi, dalam Pasal 23 UU ITE yang menyatakan bahwa:

(1) Setiap penyelenggara negara, Orang, Badan Usaha, dan/atau masyarakat berhak memiliki Nama Domain berdasarkan prinsip pendaftar pertama.

(2) Pemilikan dan penggunaan Nama Domain sebagaimana dimaksud pada ayat (1) harus didasarkan pada iktikad baik, tidak melanggar prinsip persaingan usaha secara sehat, dan tidak melanggar hak Orang lain.

(3) Setiap penyelenggara negara, Orang, Badan Usaha, atau masyarakat yang dirugikan karena penggunaan Nama Domain secara tanpa hak oleh Orang lain, berhak mengajukan gugatan pembatalan Nama Domain dimaksud.

Dalam penjelasan Pasal 23 ayat (1) UU ITE dinyatakan bahwa nama domain berupa alamat atau jati diri penyelenggara negara, Orang, Badan Usaha, dan/ atau masyarakat, yang perolehannya didasarkan pada prinsip pendaftar pertama (first come first serve). Prinsip pendaftar pertama berbeda antara ketentuan dalam nama domain dan dalam bidang hak kekayaan intelektual karena tidak diperlukan pemeriksaan substantif, seperti pemeriksaan dalam pendaftaran merek dan paten.

Penjelasan ayat (2) menyatakan bahwa yang dimaksud dengan "melanggar hak Orang lain", misalnya melanggar merek terdaftar, nama badan hukum terdaftar, nama orang terkenal, dan nama sejenisnya yang pada intinya merugikan Orang lain.

Penggunaan nama domain secara tanpa hak sebagaimana diatur dalam ayat (3) dijelaskan sebagai pendaftaran dan penggunaan nama domain yang sematamata ditujukan untuk menghalangi atau menghambat orang lain untuk menggunakan nama yang intuitif dengan keberadaan nama dirinya atau nama produknya, atau untuk mendompleng reputasi Orang yang sudah terkenal atau ternama, atau untuk menyesatkan konsumen.

Ketentuan yang terkait dengan Pasal 23 tersebut adalah Pasal 38 ayat (1) UU ITE yang memberikan dasar hukum untuk melakukan gugatan ganti rugi perdata terhadap pihak yang menyelenggarakan sistem elektronik dan/atau menggunakan teknologi informasi yang menimbulkan kerugian. ${ }^{17}$

\section{METODE}

Metode pendekatan yang digunakan dalam penelitian ini adalah yuridis normatif yang menitikberatkan penelitian pada ketentuan hukum yang berlaku. Dalam hal ini dilakukan pengkajian terhadap UU ITE, dan UU Merek. Spesifikasi penelitian ini adalah deskriptif analitis, yaitu dengan memberikan fakta-fakta penggunaan nama orang terkenal sebagai nama domain yang melanggar hak orang terkenal tersebut, serta menganalisis ketentuan UU ITE dan UU Merek yang dapat dijadikan sebagai dasar hukum gugatan ganti rugi.Tahap penelitian ini meliputi penelitian dengan studi kepustakaan. Penelitian kepustakaan dilakukan untuk memperoleh bahan hukum primer berupa bahan hukum yang mengikat seperti peraturan perundang-undangan nasional dan instrumen hukum internasional sebagaimana tersebut dalam metode pendekatan, dan bahan hukum tersier yang berupa ensiklopedia dan berbagai artikel di media cetak dan elektronik. Teknik pengumpulan data yang digunakan adalah studi dokumen yang dilakukan terhadap data sekunder untuk mendapatkan landasan teoritis, pendapatpendapat atau tulisan-tulisan para ahli atau pihak lain berupa informasi baik dalam bentuk formal maupun data melalui naskah resmi.Data yang diperoleh melalui pengumpulan data dan studi kepustakaan disusun secara sistematis untuk kemudian dianalisis secara yuridis kualitatif guna memperoleh kesimpulan atas permasalahan yang dikaji.

\section{HASIL DAN PEMBAHASAN}

Kementerian Pemberdayaan Aparatur Negara dan Reformasi Birokrasi (Kemenpanrb) memasukkan "kota" sebagai bagian dari daftar kelembagaan nasional, selain Kementerian, Lembaga Pemerintah Non Kementrian (LPNK), dan sebagainya. ${ }^{18}$

${ }^{17}$ Selengkapnya Pasal 38 UU ITE menyatakan:

(1) Setiap Orang dapat mengajukan gugatan terhadap pihak yang menyelenggarakan Sistem Elektronik dan/atau menggunakan Teknologi Informasi yang menimbulkan kerugian.

(2) Masyarakat dapat mengajukan gugatan secara perwakilan terhadap pihak yang menyelenggarakan Sistem Elektronik dan/atau menggunakan Teknologi Informasi yang berakibat merugikan masyarakat, sesuai dengan ketentuan Peraturan Perundang-undangan.

${ }^{18}$ http://www.menpan.go.id/daftar-kelembagaan-2 
Tabel 2. Daftar Nama Lembaga Non Kementerian Di Indonesia

\begin{tabular}{clcc}
\hline 1. & Kesekretariatan Lembaga Negara & $:$ & 7 \\
2. & Kementerian & $:$ & 34 \\
3. & Lembaga Setingkat Menteri & $:$ & 4 \\
4. & Lembaga Pemerintah Non & $:$ & 28 \\
5. Lementerian (LPNK) & $:$ & 88 \\
6. Lembaga Non Struktural & $:$ & 2 \\
7. & Provinsi & $:$ & 34 \\
8. Kabupaten & $:$ & 398 \\
9. & Kota & $:$ & 93 \\
\hline
\end{tabular}

Bank Indonesia, dalam websitenya, bahkan memasukkan nama-nama kota sebagai bagian dari Lembaga Nasional yang menjadi tautan websitenya, sebagai berikut:

Berdasarkan kedua sumber tersebut, jelas bahwa nama-nama kota merupakan bagian dari lembaga nasional maupun lembaga pemerintah. Pemerintah kota berdasarkan hukum keperdataan dapat dipandang sebagai suatu badan hukum yang mampu memiliki hak dan kewajiban keperdataan, termasuk memiliki hak untuk memiliki merek atau nama domain. Hak kepemilikan nama domain oleh pemerintah kota juga diatur dalam Pasal 23 ayat (1) UU ITE yang menyatakan bahwa,
"Setiap penyelenggara negara, Orang, Badan Usaha, dan/atau masyarakat berhak memiliki Nama Domain berdasarkan prinsip pendaftar pertama". Selanjutnya dalam ayat (3) dinyatakan bahwa: "Setiap penyelenggara negara, Orang, Badan Usaha, atau masyarakat yang dirugikan karena penggunaan Nama Domain secara tanpa hak oleh Orang lain, berhak mengajukan gugatan pembatalan Nama Domain dimaksud."

Berdasarkan ketentuan Pasal 23 ayat (1) dan ayat (3) UU ITE, pemerintah kota merupakan subyek hukum yang berhak memiliki nama domain, bahkan berhak pula mempertahankan haknya untuk memiliki dan menggunakan nama domain dari pihak lain yang tidak berhak (cybersquatter).

Hak Pemerintah kota untuk mengajukan gugatan ganti rugi perdata kepada pihak lain yang menggunakan nama kotanya sebagai nama domain secara tanpa hak juga disediakan dasar hukumnya dalam pengaturan Pasal 38 ayat (1) UU ITE yang menyatakan: "Setiap Orang dapat mengajukan gugatan terhadap pihak yang menyelenggarakan Sistem Elektronik dan/atau menggunakan Teknologi Informasi yang menimbulkan kerugian."

Pihak lain yang menggunakan nama kota sebagai nama domain, telah memenuhi unsur "pihak yang menyelenggarakan Sistem Elektronik dan/ atau menggunakan Teknologi Informasi”. Kerugian yang diderita pemerintah kota akibat kegiatan

Tabel 3. Daftar Nama Kota dan Lembaga Nasional Menurut Bank Indonesia

\begin{tabular}{|c|c|c|}
\hline $\begin{array}{l}\text { Lembaga Internasional } \\
\text { Institusi Pemerintah }\end{array}$ & \multicolumn{2}{|c|}{ Lembaga Nasional } \\
\hline $\begin{array}{l}\text { Institusi Pemerintah } \\
\text { - Pemerintah Indonesia } \\
\text { · Kementrian Badan Usaha Milik Negara } \\
\text { - Badan Pusat Statistik } \\
\text { · Badan Koordinasi Penanaman Modal } \\
\text { · Kamar Dagang dan Industri } \\
\text { - Direktorat Jendral Pajak } \\
\text { - Direktorat Jendral Bea Cukai } \\
\text { - Badan Pengembangan Ekspor Nasional } \\
\text { - Pusat Pelaporan dan Analisis Transaksi Keuangan } \\
\text { (PPATK) } \\
\text { - Badan Sertifikasi Manajemen Resiko } \\
\text { - Economic and Financial Data for Indonesia } \\
\text { - Departemen Keuangan Republik Indonesia } \\
\text { - Badan Perencanaan Pembangunan Nasional } \\
\text { - Penilai Harga Efek di Indonesia } \\
\text { - Badan Pemeriksa Keuangan } \\
\text { - Badan Pengawasan Pasar Modal dan Lembaga } \\
\text { Keuangan }\end{array}$ & $\begin{array}{l}\text { - Provinsi Nanggroe Aceh Darussalam } \\
\text { - Provinsi Sumatera Utara } \\
\text { - Provinsi Riau } \\
\text { - Provinsi Sumatera Barat } \\
\text { - Provinsi Sumatera Selatan } \\
\text { - Provinsi Bengkulu } \\
\text { - Provinsi Jambi } \\
\text { - Provinsi DKI Jakarta } \\
\text { - Provinsi Jawa Barat } \\
\text { - Provinsi DI Yogyakarta } \\
\text { - Provinsi Jawa Tengah } \\
\text { - Provinsi Jawa Timur } \\
\text { - Provinsi Kalimantan Barat } \\
\text { - Provinsi Kalimantan Selatan } \\
\text { - Provinsi Kalimantan Tengah } \\
\text { - Provinsi Kalimantan Timur } \\
\text { - Provinsi Sulawesi Selatan } \\
\text { - Provinsi Sulawesi Tenggara } \\
\text { - Provinsi Sulawesi Utara } \\
\text { - Provinsi Sulawesi Tengah } \\
\text { - Provinsi Nusa Tenggara Timur } \\
\text { - Provinsi Papua } \\
\text { - Kota Ambon } \\
\text { - Kota Balikpapan } \\
\text { - Kota Bandung } \\
\text { Pota Banyumas } \\
\text { Patam }\end{array}$ & 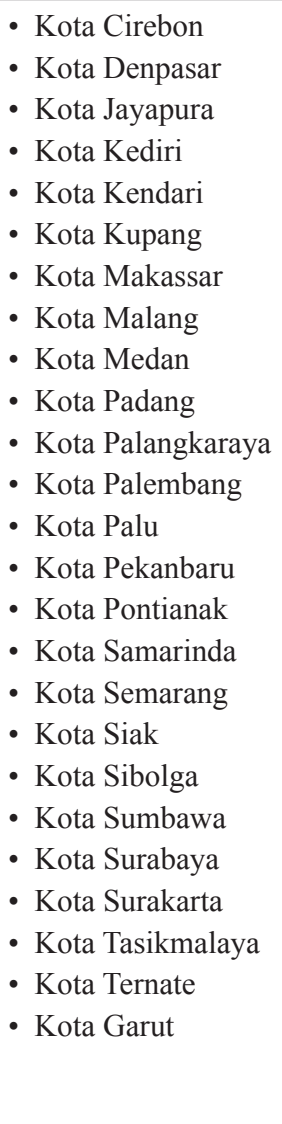 \\
\hline
\end{tabular}


cybersquatting adalah terhalangnya hak pemerintah kota untuk menggunakan nama kotanya sebagai nama domain, penyesatan konsumen, serta hilangnya potensi keuntungan yang seharusnya diperoleh oleh pemerintah kota yang menggunakan nama domain dalam rangka melakukan perdagangan secara elektronik maupun dari pendapatan iklan.

Dengan demikian, penggunaan nama kota oleh para cybersquatter merupakan pelanggaran hak penyelenggara Negara, dalam hal ini pemerintah kota, untuk memiliki nama domain berdasarkan Pasal 23 ayat (2) UU ITE, yang dapat dilakukan gugatan ganti rugi berdasarkan Pasal 38 UU ITE.

C.F. Strong mengartikan pemerintah dalam arti luas ${ }^{19}$ sebagai organisasi negara yang utuh dengan segala alat kelengkapan negara yang memiliki fungsi legislatif, eksekutif dan yudikatif. Dengan kata lain, negara dengan seluruh alat kelengkapannya merupakan pengertian pemerintahan dalam arti yang luas. Pengertian pemerintahan dalam arti yang sempit, hanya mengacu pada satu fungsi saja, yakni fungsi eksekutif. Berdasarkan pengertian ini, maka nama kota termasuk dalam ruang lingkup lembaga pemerintah sebagaimana dimaksud dalam Pasal 6 ayat (3) UU Merek.

Pasal 6 ayat (3) huruf b UU Merek tidak secara eksplisit menyebutkan nama kota sebagai obyek yang dilindungi, melainkan hanya menyebutkan secara eksplisit frase "nama lembaga nasional". Baru pada Pasal 6 ayat (3) huruf c, ada penyebutan frase "Lembaga Pemerintah",akan tetapi pengaturannya ditujukan kepada penggunaan tanda atau cap atau stempel resmi.

Frase "lembaga nasional" sebagaimana dimaksudkan dalam Pasal 6 ayat (3) huruf b UU Merek tersebut adalah untuk membedakannya dengan lembaga internasional. Dengan demikian, dapat diartikan bahwa yang dimaksudkan dengan "lembaga nasional" tersebut adalah nama-nama lain dalam struktur organisasi Negara dan/ atau pemerintahan selain nama "Negara Indonesia".

Berdasarkan uraian tersebut, penggunaan nama kota sebagai nama domain internet tanpa ijin dapat ditafsirkan atau dianalogikan sebagai pelanggaran terhadap hak lembaga nasional dan/atau lembaga pemerintah sebagaimana yang diatur dalam Pasal 6 ayat (3) guruf b dan huruf c UU Merek.

Kementerian Komunikasi Dan Informatika Dalam Peraturan Menteri Komunikasi Dan Informatika Nomor 28 /Per/M.Kominfo/9/2006 Tentang Tentang Penggunaan Nama Domain go.id Untuk Situs Web Resmi Pemerintahan Pusat Dan Daerah, menyebutkan dalam Pasal 5 bahwa: "Pemerintahan terdiri dari:

a. Lembaga Negara (Dewan Perwakilan Rakyat, Badan Pemeriksa Keuangan, Mahkamah Agung, dan lainlain);

b. Lembaga pemerintah (Presiden dan Wakil Presiden,

19 Strong, C.F. Modern Political Constitution, London, Sidgwick and Jackson, 1963.
Menteri, Lembaga Pemerintah Non Departemen, Pemerintah Daerah);

c. Komisi (Komisi yang dibentuk berdasarkan undang-undang)."

Pemerintah Daerah yang pada umumnya menggunakan nama kota, jelas merupakan bagian dari Lembaga Pemerintah sebagaimana dimaksud dalam Pasal 6 ayat (3) UU Merek.

Dalam Negara kesejahteraan (welfare state) yang kemudian juga dikenal sebagai Negara administrasi (administrative state) terutama pada paruh pertama abad XX yang lalu, fungsi pemerintah beserta aparaturnya terhadap masyarakat adalah melayani (service function) dan mengatur (regulating function).Kedua fungsi tersebut dijalankan untuk dapat mensejahterakan rakyat. Pemerintah berupaya memenuhi dan melayani sendiri kebutuhan-kebutuhan masyarakat, sehingga pemerintah berperan sebagai produsen barang dan layanan yang diperlukan oleh masyarakat.Disamping itu pemerintah mengatur segala bidang agar segala sesuatu tertib dan teratur.

Bagi Negara yang sedang berkembang, yang sedang membangun, seperti halnya Indonesia, fungsi pelayanan dan pengaturan saja tidak cukup, karena pemerintah harus pula berupaya menjadikan masyarakat mampu dan mau membangun dirinya sendiri. Pemerintah harus dapat menciptakan kondisi yang kondusif, sehingga tumbuh kreatifitas dan oto aktifitas masyarakat untuk membangun dalam memenuhi kebutuhan sendiri. Oleh karena itu, fungsi aparatur negara pada Negara yang sedang berkembang adalah :

1. melayani masyarakat,

2. mengayomi masyarakat, dan

3. menumbuhkembangkan prakarsa dan peranserta masyarakat dalam pembangunan.

Fungsi yang ketiga tersebut sebenarnya justru harus menjadi muara bagi kedua fungsi yang lain, artinya pelayanan dan pengayoman harus sekaligus diarahkan agar masyarakat mampu berprakarsa dan berperan serta dengan baik dalam pembangunan. Fungsi yang ketiga ini sebenarnya sejalan pula dengan paradigma baru dalam administrasi Negara, yaitu fungsi pemberdayaan (empowering). Paradigma baru dalam administrasi Negara menekankan bahwa pemerintah tidak lagi harus menjadi produsen semua barang dan layanan yang diperlukan masyarakat, tetapi pemerintah harus lebih berperan sebagai fasilitator dan regulator, sehingga masyarakat mampu dengan baik memenuhi kebutuhannya sendiri.

Pemerintah dalam melakukan kegiatannya seharihari tampil dengan dua kedudukan, yaitu sebagai wakil dari badan hukum (pelaku hukum keperdataan) dan wakil dari jabatan pemerintahan (pelaku hukum publik). Selaku pelaku hukum keperdataan yang melakukan berbagai 
perbuatan hukum keperdataan seperti mengikatkan perjanjian jual beli, sewa menyewa, pemborongan dan sebagainya yang dijelmakan dalam kualitas badan hukum. Dalam posisi ini kedudukan pemerintah tidak ada bedanya dengan seseorang atau badan hukum perdata pada umumnya, yaitu diatur dan tunduk pada ketentuanketentuan hukum keperdataan.

Dalam regulasi merek di Amerika Serikat dan Inggris, terdapat ketentuan tentang "common law mark" atau "common law trademark", yaitu merek yang memperoleh perlindungan bukan berdasarkan pendaftaran, melainkan berdasarkan maksud dan penggunaannya dalam praktik. ${ }^{20}$ Menurut definisi dari Bitlaw, "the term "common law marks" indicates that the trademark rights that are developed through use are not governed by statute. Instead, common law trademark rights have been developed under a judicially created scheme of rights governed by state law. (Common law marks adalah hak merek yang timbul karena pemakaian bukan karena pendaftaran. Hak ini terutama lahir dalam putusan-putusan pengadilan.- terjemahan bebas penulis). Dalam kedua sistem hukum tersebut, nama-nama yang dilindungi oleh hukum merek tetapi tidak didaftarkan, harus membuktikan bahwa nama tersebut memiliki "secondary meaning" yang menjadi unsur pembeda (distinctive), dan bukan hanya sebagai nama yang memiliki fungsi penggambaran (descriptive). ${ }^{21} \mathrm{Hal}$ ini berarti bahwa nama kota tersebut harus "terasosiasi atau terkait" dengan asal produk, tidak hanya menunjukkan lokasi produksi dari produk tersebut. Dengan kata lain, penggunaan nama kota sebagai nama domain tersebut, meskipun nama kotanya belum didaftarkan sebagai merek, menimbulkan kebingungan atau kekeliruan bagi masyarakat terhadap daerah yang memproduksinya.

Beberapa kasus penggunaan nama kota sebagai nama domain, pada umumnya dimenangkan oleh pemerintah kota yang juga mendaftarkan nama kotanya sebagai merek. Namun dalam hal nama kota tidak didaftarkan sebagai merek, pemerintah kota dimaksud agak kesulitan dalam membuktikan bahwa nama kotanya memiliki secondary meaning. Beberapa kasus yang dimenangkan pemerintah kota berdasarkan secondary meaning yang disyaratkan common law mark antara lain kasus Manchester Airport PLC v Club Club Limited, Wembley National Stadium Limited v Bob Thomson, dan Sydney Airport Corporation v John Crilly. Pada ketiga kasus tersebut, nama-nama kota telah digunakan dalam kegiatan perdagangan barang dan/ atau jasa sehingga dianggap telah memiliki secondary meaning. ${ }^{22}$

Penggunaan nama kota sebagai nama domain di Indonesia mulai banyak terjadi, antara lain dalam

\footnotetext{
${ }^{20}$ Philips, Jeremy and Ilanah Simon, Trade Mark Use, Oxford University Press, New York, 2005, hlm. 276

${ }^{21}$ Lindsay David, InternationalInternational Domain Names Law, ICANN and the UDRP, Hart Publishing, Oxford and Portland, Oregon, 2007, hlm.229.

${ }^{22}$ Ibid, hlm. 230-231
}

nama domain kotayogyakarta.com, kotajogja.com, bandung.com, bali.com. Nama domain lain yaitu JawaTimur.com dan JawaBarat.com yang didaftarkan oleh Kristianto Siswanto ${ }^{23}$, nama domain Jakarta.com dan Jakarta.us juga telah ada yang mendaftarkan ${ }^{24}$. Daftar nama-nama kota di Indonesia yang telah terdaftar dapat dicek melalui https:// portal.qwords.com/domainchecker.php. Banyaknya penggunaan dan pendaftaran nama domain yang mengandung nama kota ini sangat berpotensi melahirkan kasus-kasus sengketa nama domain baru di Indonesia.

Dalam menerima gugatan ganti rugi perdata akibat pelanggaran terhadap nama kota, baik sebagai merek terdaftar maupun tidak terdaftar (yang dianalogikan dengan indikasi geografis dan/atau indikasi asal) sebagai nama domain secara tanpa hak, selain erdasarkan UU ITE, hakim mendasarkan pertimbangan hukumnya pada UU Merek. Hal ini dapat dilakukan dengan mendesak hakim untuk melakukan penemuan hukum (rechtsvinding) dengan cara melakukan penafsiran gramatikal dan telelogis atau sosiologis terhadap beberapa ketentuan dalam UU Merek, antara lain mengenai pengertian dan ruang lingkup merek, prinsip itikad baik, perluasan ruang lingkup hak ekslusif merek, perluasan hak ekslusif indikasi geografis, persamaan merek, persamaan indikasi geografis, persamaan indikasi asal, dan gugatan ganti rugi perdata. sementara menunggu revisi UU Merek.

Penemuan hukum dimaksud yang dilakukan oleh Hakim, mendasarkan keoada UU Kekuasaan Kehakiman. Berdasarkan ketentuan Pasal 10 ayat (1) UU Nomor 48 Tahun 2009 tentang Kekuasaan Kehakiman, Lembaran Negara Tahun 2009 Nomor 157 menjelaskan bahwa, "Pengadilan dilarang menolak untuk memeriksa, mengadili dan memutus suatu perkara yang diajukan dengan dalih bahwa hukum tidak ada atau kurang jelas, melainkan wajib untuk memeriksa dan mengadilinya". Ketentuan pasal ini mengisyaratkan kepada hakim bahwa apabila terjadi suatu peraturan perundangundangan yang belum jelas atau belum mengaturnya, hakim harus bertindak berdasar inisiatifnya sendiri untuk menyelesaikan perkara tersebut. Dalam hal ini hakim harus berperan untuk menentukan apa yang merupakan hukum, sekalipun peraturan perundang-undangan tidak dapat membantunya. Tindakan inilah yang dinamakan penemuan hukum. ${ }^{25}$

Dalam rangka menemukan hukum ini, isi ketentuan Pasal 10 ayat (1) ini hendaknya dihubungkan dengan ketentuan Pasal 5 ayat (1) yang menyatakan bahwa, "Hakim dan hakim konstitusi wajib menggali, mengikuti, dan memahami nilai-nilai hukum dan rasa keadilan yang hidup dalam masyarakat". Ketentuan

\footnotetext{
${ }^{23} \mathrm{http}$ //www.ebizzasia.com/0110-2003/enterprise,0110,03.htm

$24 \mathrm{https}: / /$ portal.qwords.com/orderdomainphp?action=showDomains $\&$ directForm $=\&$ checkFirstAvailable $=\&$ checkfirst Available Condition $=1 \&$ domains $=$ jakarta $\& \mathrm{tld}[0]=. \operatorname{com} \& \mathrm{tld}[1]=$ om\&tld $[2]=$. asia\&tld[3]=.org\&tld $[4]=$. me\&tld $[5]=$. us\&tld $[6]=. x y z$

25 Yudha Bhakti Ardhiwisastra, op.cit., hlm.6-7.
} 
ini dapat diartikan bahwa karena hakim merupakan perumus dan penggali dari nilai-nilai hukum yang hidup dalam masyarakat, ia seharusnya dapat mengenal, merasakan, dan mampu menyelami perasaan hukum dan rasa keadilan yang hidup dalam masyarakat. Dengan demikian, hakim dapat memberikan putusan yang sesuai dengan hukum dan rasa keadilan masyarakat. ${ }^{26}$

Jadi, tugas penting dari hakim ialah menyesuaikan undang-undang dengan hal-hal nyata di masyarakat. Apabila undang-undang tidak dapat dijalankan menurut arti katanya, hakim harus menafsirkannya. Dengan lain perkataan, apabila undang-undang tidak jelas, hakim wajib menafsirkannya sehingga ia dapat membuat suatu keputusan yang adil dan sesuai dengan maksud hukum yaitu mencapai kepastian hukum. Karena itu, orang dapat mengatakan bahwa menafsirkan undang-undang adalah kewajiban hukum dari hakim. ${ }^{27}$

Keberadaan dan pengakuan data elektronik dalam dunia perbankan selama ini harus disikapi sebagai suatu praktik atau hukum kebiasaan yang terjadi di masyarakat yang perlu digali, dikaji dan dipertimbangkan oleh hakim dalam menghadapi kasus pelanggaran nama domain di Indonesia. Hal ini penting mengingat bahwa hukum kebiasaan dan praktik yang terjadi di masyarakat juga merupakan sumber hukum, selain undang-undang itu sendiri. Dengan demikian, keberadaan alat bukti elektronik termasuk nama domain, email, dan lain-lain haruslah diakui keabsahannya dan diterima sebagai alat bukti khususnya dalam penyelesaian gugatan perdata atas pelanggaran merek sebagai nama domain. ${ }^{28}$

Penyelesaian kasus nama domainakan lebih efektif jika menggunakan pendekatan perdata mengingat bahwa para pihak akan menemukan keadilan secara proposional, karena pihak yang secara ekonomi dirugikan akan memperolah ganti-rugi atas kerugian yang dideritanya, sementara pihak yang melakukan perbuatan melawan hukum juga secara setimpal akan menjadi berkewajiban untuk memberikan ganti-rugi sebagai ganjaran atas perbuatannya itu. ${ }^{29}$

Selain itu, pemerintah kota juga dapat mengajukan gugatan pembatalan sekaligus gugatan ganti rugi perdata di Amerika Serikat berdasarkan ACPA, sebagaimana yang dilakukan oleh Pemerintah Kota Barcelona terhadap tergugat yang berdomisili di Amerika Serikat dan terdaftar nama domainnya pada registrar NSI yang berkedudukan di Amerika Serikat. ${ }^{30}$

26 Ibid, hlm. 7.

27 Ibid, hlm. 8.

28 Pasal 5 ayat (1) UU ITE menyatakan bahwa, "Informasi elektronik dan atau hasil cetakdari informasi elektronik merupakan alat bukti yang sah dan memiliki akibat hukum yang sah."

29 Mieke Komar Kantaatmadja et.al., op.cit., hlm 112.

30 Owens, Ryan R., Domain-Name Dispute-Resolution after Sallen v. Corinthians Licenciamentos \& Barcelona.com, Inc. v. Excelentisimo Ayuntameiento De Barcelona, Berkeley Technology Law Journal, Vol. 18 Issue. 1, Art. 16, January, 2003, hlm. 273-274

\section{SIMPULAN}

Penggunaan nama kota sebagai nama domain oleh pihak lain tanpa ijin merupakan suatu bentuk cybersquatting yang melanggar hak pemerintah kota sebagaimana diatur dalam Pasal 23 ayat (2) UU ITE dan dapat digugat ganti rugi perdata berdasarkan Pasal 38 UU ITE. Pelanggaran dimaksud dalam point 1 juga dapat dianalogikan dari ketentuan Pasal 6 ayat (3) huruf b dan c UU Merek.

Hakim Indonesia dalam menghadapi sengketa penggunaan nama kota oleh pihak lain tanpa ijin sebagai nama domain tetap dapat menerima dan memeriksa sengketa tersebut berdasarkan ketentuan Pasal 5 dan Pasal 10 ayat (1) UU Nomor 48 Tahun 2009 tentang Kekuasaan Kehakiman, dengan melakukan penfsiran hukum, berupa penafsiran gramatikal dan teleologis/sosiologis terhadap beberapa ketentuan UU Merek yang terkait dengan cybersquatting. UU ITE harus dijadikan dasar pertimbangan dan UU Merek harus dijadikan objek penafsiran, mengingat substansi objek yang diaturnya yaitu nama orang terkenal, telah diatur dalam UU Merek.

\section{DAFTAR PUSTAKA}

Budi Agus Riswandi, Hukum dan Internet di Indonesia, Yogyakarta, UII Press, 2003

Strong, C.F. Modern Political Constitution, London, Sidgwick and Jackson, 1963.

David Baumer, J.C. Poindexter, Cyberlaw and E-Commerce: Security, Risk Management, and Control, New York: McGraw-Hill, 2002

David Lindsay, InternationalInternational Domain Names Law, ICANN and the UDRP, Hart Publishing, Oxford and Portland, Oregon, 2007

H. OK. Saidin, Aspek Hukum Hak Kekayaan Intelektual - Intellectual Property Rights, Jakarta, PT. Raja Grafindo Persada. 2003

http://www.bi.go.id/id/Tautan-Lembaga-Nasional. aspx

http://www.ebizzasia.com/0110-2003/ enterprise, $0110,03 . \mathrm{htm}$

http://www.icann.org/udrp/approved-providers.htm.

http://www.infokomputer.com/2015/02/berita/beritareguler/hingga-akhir-2014-nama-domaincapai-284-juta/

http://www.menpan.go.id/daftar-kelembagaan-2

https://portal.qwords.com/n.p?action=showDomain $\mathrm{s} \&$ directForm $=1 \&$ checkFirstAvailable $=1 \& \mathrm{c}$ heckFirstAvailableCondition=1\&domains= 
jakarta\&tld[0]=. $\operatorname{com} \& \operatorname{tld}[1]=$. com\&tld[2] $=$. asia\&tld[3] $=. \operatorname{org} \& \operatorname{tld}[4]=. \operatorname{me} \& \operatorname{tld}[5]=$. us\&tld[6]=.xyz

https://www.pandi.id/content/statistik

ICANN - UDRP Rules, http://www.icann.org/udrp/ udrp-rules-24oct99.htm
Mieke Komar Kantaatmadja, Cyberlaw - Suatu Pengantar. Jakarta, ELIPS II. 2002

Philips, Jeremy and Ilanah Simon, Trade Mark Use, Oxford University Press, New York, 2005

Yudha Bhakti Ardhiwisastra, Penafsiran dan Konsytruksi Hukum, , Bandung, Alumni. 2000 